\title{
PPARalpha-mediated effects of dietary lipids on intestinal barrier
} gene expression Heleen M de Vogel-van den Bosch 1,2, Meike Bünger1,2, Philip J de Groot ${ }^{1,2}$,
Hanneke Bosch-Vermeulen1,2, Guido JEJ Hooiveld ${ }^{1,2}$ and Michael Müller*1,2

Address: ${ }^{1}$ Nutrition, Metabolism and Genomics group, Division of Human Nutrition, Wageningen University, PO Box 8129, NL-6700EV, Wageningen, the Netherlands and 2Nutrigenomics Consortium, TI Food and Nutrition, P.O. Box 557, NL-6700AN, Wageningen, the Netherlands

Email: Heleen M de Vogel-van den Bosch - heleen.vandenbosch@fys.unimaas.nl; Meike Bünger - meike.bunger@wur.nl; Philip J de Groot - philip.degroot@wur.nl; Hanneke Bosch-Vermeulen - h.bosch@deltacell.nl; Guido JEJ Hooiveld - guido.hooiveld@wur.nl; Michael Müller* - michael.muller@wur.nl

* Corresponding author

Published: 19 May 2008

BMC Genomics 2008, 9:231 doi:10.1/86/|47|-2164-9-23।
Received: 8 November 2007

Accepted: 19 May 2008

This article is available from: http://www.biomedcentral.com/I47I-2I64/9/23I

(c) 2008 de Vogel-van den Bosch et al; licensee BioMed Central Ltd.

This is an Open Access article distributed under the terms of the Creative Commons Attribution License (http://creativecommons.org/licenses/by/2.0), which permits unrestricted use, distribution, and reproduction in any medium, provided the original work is properly cited.

\begin{abstract}
Background: The selective absorption of nutrients and other food constituents in the small intestine is mediated by a group of transport proteins and metabolic enzymes, often collectively called 'intestinal barrier proteins'. An important receptor that mediates the effects of dietary lipids on gene expression is the peroxisome proliferator-activated receptor alpha (PPAR $\alpha$ ), which is abundantly expressed in enterocytes. In this study we examined the effects of acute nutritional activation of PPAR $\alpha$ on expression of genes encoding intestinal barrier proteins. To this end we used triacylglycerols composed of identical fatty acids in combination with gene expression profiling in wild-type and PPAR $\alpha$-null mice. Treatment with the synthetic PPAR $\alpha$ agonist WYI4643 served as reference.
\end{abstract}

Results: We identified 74 barrier genes that were PPAR $\alpha$-dependently regulated 6 hours after activation with WYI 4643. For eicosapentaenoic acid (EPA), docosahexaenoic acid (DHA) and oleic acid (OA) these numbers were 46,41 , and 19, respectively. The overlap between EPA-, DHA-, and WYI4643-regulated genes was considerable, whereas OA treatment showed limited overlap. Functional implications inferred form our data suggested that nutrient-activated PPAR $\alpha$ regulated transporters and phase I/II metabolic enzymes were involved in a) fatty acid oxidation, b) cholesterol, glucose, and amino acid transport and metabolism, c) intestinal motility, and d) oxidative stress defense.

Conclusion: We identified intestinal barrier genes that were PPAR $\alpha$-dependently regulated after acute activation by fatty acids. This knowledge provides a better understanding of the impact dietary fat has on the barrier function of the gut, identifies PPAR $\alpha$ as an important factor controlling this key function, and underscores the importance of PPAR $\alpha$ for nutrient-mediated gene regulation in intestine. 


\section{Background}

The small intestine is the primary site for digestion and selective absorption of nutrients and other food constituents. Absorption of these molecules across the intestinal epithelium is mediated mainly by multiple transmembrane transporters that principally belong to two superfamilies, namely the solute carrier (SLC) and the ATP Binding Cassette (ABC) superfamily of transporters. SLC transporters located at the apical membrane of enterocytes are responsible for the selective uptake of macronutrients, such as di- and tripeptides, hexoses and fatty acids [1]. In contrast, $A B C$ transporters are efflux transporters responsible for the active removal of substances, including nutrients such as cholesterol, regulating their intracellular concentrations [2]. Besides their presence in plasma membranes, SLC and ABC transporters are also located in intracellular organelles, such as mitochondria or peroxisomes, thus regulating intracellular and transcellular solute transport.

In addition, it has become clear that the small intestine is an important metabolic active organ, to a great extend responsible for the first-pass metabolism of nutrients and xenobiotics $[3,4]$. Numerous metabolic reactions occur in enterocytes, including those typically referred to as phase I and phase II metabolism. Phase I metabolism includes oxidative, peroxidative, and reductive metabolism of endogenous compounds and drugs, mediated by cytochrome P450 isoenzymes (CypP450s) [5]. Phase II metabolism often succeeds phase I metabolism and yields mainly more hydrophilic metabolites, mostly by conjugation, thereby increasing the water solubility of lipophilic compounds. The most important phase II enzymes are sulfotransferases (Sults) [6,7], UDP-glucuronosyltransferases (Ugts) [8], glutathione S-transferases (Gsts) [9,10], $\mathrm{N}$-acetyltransferases (Nats) [11], and epoxide hydrolases (Ephs) [12]. Several ABC transporters are responsible for the excretion of metabolites resulting from phase I and phase II enzymatic transformations [2].

There is increasing interest in the molecular mechanisms underlying the beneficial or adverse effects of foods and food components. Nutrients impact gene expression mainly by activating or suppressing specific transcription factors $[13,14]$. The most important group of transcription factors involved in mediating the effect of nutrients and their metabolites on gene transcription is the superfamily of nuclear receptors, which consists of 48 members in the human genome [15]. This superfamily is subdivided into six families [16], of which the NR1 family is most relevant to nutrition. One important group of receptors that mediates the effects of dietary fatty acids and its derivatives on gene expression are the Peroxisome Proliferator Activated Receptors (PPARs, NR1C) [16-18]. Three PPAR isotypes, $\alpha$ (NR1C1), $\delta$ (also called $\beta$ ) (NR1C2), and $\gamma$ (NR1C3) are distinguished and characterized by different biological roles. Transcriptional regulation by PPARs requires heterodimerization with the retinoid $\mathrm{X}$ receptor (RXR; NR2B) $[16,19,20]$. When activated by an agonist, the PPAR/RXR heterodimer stimulates transcription via binding to DNA response elements (PPREs) present in and around the promoter of target genes. Besides upregulating gene expression, PPARs are also able to repress transcription by directly interacting with other transcription factors and interfere with their signaling pathways, a mechanism commonly referred to as transrepression [21].

PPAR $\alpha$ has been shown to be expressed at a high level in the small intestine [22]. Moreover, the average Western diet contains a high amount of triacylglycerols [23] that are hydrolyzed to monoacylglycerol and free fatty acids before entering the enterocyte [24]. As a result the small intestine is frequently exposed to high levels of natural PPAR $\alpha$ agonists. However, currently little is known about the effects of PPAR $\alpha$ activation by dietary fats on gene expression in small intestine. Although in several studies small intestinal gene expression was studied after high-fat feeding [25-27], the specific role of PPAR $\alpha$ remains to be elucidated.

Here, we take advantage of a unique experimental design using triglycerides composed of identical fatty acids in combination with gene expression profiling to examine the effects of individual dietary fatty acids on intestinal gene expression in mice. By conducting these experiments in wild-type and PPAR $\alpha$-/- mice, and by limiting the exposure time to 6 hours, we were able to elucidate the specific, direct contribution of PPAR $\alpha$ in regulating the expression of transport and phase I/II metabolism genes in small intestine.

\section{Results and discussion Effect of acute PPAR $\alpha$ activation with OA, EPA, DHA and WYI4643}

In this study we investigated the role of PPAR $\alpha$ on the expression of genes encoding for transport proteins and phase I/II metabolic enzymes, collectively called barrier proteins, which are responsible for the selective absorption and metabolism of food components. Since we are specifically interested in the role PPAR $\alpha$ plays in nutrientmediated gene regulation, we used and compared in our studies 3 natural agonists normally found in the diet [oleic acid (OA, C18:1), eicosapentaenoic acid (EPA, C20:5) and docosahexaenoic acid (DHA, C22:6)]. As reference we used the synthetic agonist WY14643. We analyzed gene expression 6 hours after oral gavage, thus we primarily studied the direct effects of PPAR $\alpha$ activation. This time point was chosen because in a pilot experiment we found that after an oral fat load plasma triacylglycerol 
levels peaked at 2-3 hours post loading and almost returned to basal levels after 6 hours (data not shown), indicating that at that point most of the fat bolus has passed through the enterocytes, and sufficient time remained for transcriptional events to occur. Expression of transport and phase I/II metabolism genes (barrier genes) was studied using microarrays. The Affymetrix GeneChip Mouse Genome 4302.0 array comprised of 45,038 probesets, representing 16,579 unique genes. Annotation information from Affymetrix was queried to compile a list of transport and phase I/II metabolism genes present on the array (for details, see methods section). This set consisted of 944 probesets, encoding for 529 unique genes, and was used throughout all analyses. We identified 9,426 significantly expressed genes in small intestine, of which 264 were barrier genes.

As expected, of all agonists used in this study, acute treatment with WY14643 provoked the most pronounced response, both with respect to the number of regulated genes and the magnitude of the fold changes. Treatment with WY14643 resulted in the PPAR $\alpha$-specific differential expression of 74 transport and phase I/II metabolism genes (Table 1), of which 32 were expressed at higher levels and 42 genes were reduced in wild-type mice compared to PPAR $\alpha$-null mice (for the full list of regulated genes please see additional data, Table 1). On the other hand, treatment of wild-type and PPAR $\alpha$-null mice with OA identified only 19 PPAR $\alpha$-dependently regulated barrier genes (Table 1). Of these, 13 were induced and 6 repressed (additional data, Table 2). Treatment with EPA and DHA resulted in 46 and 41 PPAR $\alpha$-dependently regulated barrier genes, respectively (Table 1 ). Activation of PPAR $\alpha$ by EPA increased the expression of 32 genes and suppressed 14 genes (additional data, Table 3), whereas for DHA these numbers were 22 and 19, respectively (additional data, Table 4).

In Bünger et al [22] we reported that under basal (control) conditions only 21 genes were differentially expressed in small intestine of wild-type mice compared to PPAR $\alpha$ null mice. The currently investigated barrier gene set includes 2 of these genes, Slc25a20 and Cyp4a10, which were both expressed at lower levels in the null mice. We found that expression of Slc25a20 was only slightly elevated after acute treatment with WY14643, EPA, and DHA, which indicates that the regulation of Slc25a20 by PPAR $\alpha$ may be of less relevance during (nutritional) activation of PPAR $\alpha$. In contrast, the fold induction of Cyp4a10 observed after acute treatment with WY14643, EPA and DHA was much larger than the basal difference, which implies that for this gene activation of PPAR $\alpha$ is of importance.

When comparing the list of barrier genes that were PPAR $\alpha$-dependently regulated after acute treatment with WY14643 with that of a long-term (5 day) exposure experiment [22], we found an overlap of 74\% (additional data, Table 5). This indicates that short-term regulation evoked with synthetic agonists is maintained for at least 5 days.

Hirai et al [28] very recently reported their study in which they identified seven nutrient and drug transporters that were PPAR $\alpha$-dependently regulated in small intestine after 3 days exposure to two synthetic agonists. In concordance with their data, we found that all except 2 of these transporters were regulated after acute treatment with WY14643 as well. In addition, we observed that these carriers were also PPAR $\alpha$-dependently regulated by DHA and EPA. Like Hirai et al, we did not observe a PPAR $\alpha$-dependent regulation of Pept1 (Slc15a1), the first intestinal nutrient transporter shown to be PPAR $\alpha$ dependently regulated during fasting $[28,29]$.

To characterize the importance of PPAR $\alpha$ in controlling expression of small intestinal transporters and phase I/II metabolic enzymes, we compared the fraction of PPAR $\alpha$ dependently regulated genes of the barrier gene set with that observed for all genes (Table 1). For treatment with OA the percentages were $7.2 \%$ and $5.4 \%$, respectively, for the set of barrier genes and all expressed genes. This difference was not statistically significant $(\mathrm{p}=0.11)$. However, the other two natural agonists showed a significantly higher percentage of regulated genes for the barrier gene set than for all genes; for EPA this percentage was $9.3 \%$ for all genes, whereas $17.4 \%$ of the barrier genes were regu-

Table I: Number of PPAR $\alpha$-dependently regulated genes after treatment with different agonists

\begin{tabular}{|c|c|c|c|c|c|c|c|c|}
\hline & \multicolumn{2}{|r|}{ OA } & \multicolumn{2}{|r|}{ EPA } & \multicolumn{2}{|c|}{ DHA } & \multicolumn{2}{|c|}{ WYI4643 } \\
\hline & All genes & Barrier genes & All genes & Barrier genes & All genes & Barrier genes & All genes & Barrier genes \\
\hline $\begin{array}{l}\text { Number of PPAR } \alpha- \\
\text { dependent regulated } \\
\text { genes }\end{array}$ & 508 & 19 & 874 & 46 & 894 & 41 & 1218 & 74 \\
\hline Percentage & 5.4 & 7.2 & 9.3 & 17.4 & 9.5 & 15.5 & 12.9 & 28.0 \\
\hline
\end{tabular}

Number of PPAR $\alpha$-dependently regulated genes and corresponding percentages for all genes and the barrier gene set after activation with OA, EPA, DHA, and WYI 4643. The percentages relate to the total number of expressed genes $(9,426)$ and all barrier genes $(264)$, respectively. 
lated $(\mathrm{p}<0.001)$. For DHA these percentages were 9.5\% and $15.5 \%$ respectively $(\mathrm{p}<0.001)$. For WY14643 we observed an even larger difference between all genes and the barrier gene set; $12.9 \%$ respectively $28.0 \%$ of the genes were regulated in a PPAR $\alpha$-dependent manner ( $\mathrm{p}<$ 0.001 ). These results imply that PPAR $\alpha$ plays an important role in regulating small intestinal gene expression of transporter and phase I/II metabolic enzymes.

\section{Overlap between OA, EPA, DHA and WYI4643 treatment} We also determined the overlap of PPAR $\alpha$-dependently regulated genes between the different treatments. Most of the genes regulated upon treatment with OA were not regulated by DHA and EPA (Figure 1A) or WY14643 (data not shown). Only four genes, i.e. Slc27a4 (Fatp4), Cyp4F16, Cyp2c65, and Abcd3 were regulated upon all 4 treatments. For these genes additional qRT-PCR analyses were performed, which confirmed the array results (Table 2 ). There was considerable overlap between the genes affected by EPA, DHA or WY14643 treatment (Figure 1B). These overlapping genes behaved the same in all treatments, i.e. they were either increased or suppressed in wild-type compared to PPAR $\alpha$-null mice upon all treatments. In Table 6 of the additional data the complete list of overlapping genes is presented. It is likely that OA treatment affected fewer genes, because the mice may be adapted to this fatty acid since they were fed a diet based on olive oil three weeks before gavage (for details, see methods section). In addition, it is generally accepted that polyunsaturated fatty acids activate PPAR $\alpha$ better than monounsaturated fatty acids [30-33], which is in line with our result that OA activated less genes PPAR $\alpha$-dependently than EPA and DHA. Although the overlap between WY14643-, EPA-, and DHA-regulated genes was high, we still observed differential gene activation between these treatments. The exact mechanism(s) underlying these differences are currently unclear, but we speculate this may be partially due to the differential recruitment of coactivators such as Src-1, Med1, Pgc1 $\alpha$, and p300 by the three agonists [34-37]. Alternatively, hitherto unknown additional signaling routes not shared by the three agonists may exist.

\section{Functional implications of acute PPAR $\alpha$ activation in small} intestine

A summary of functional outcomes of PPAR $\alpha$ activation by the agonists inferred from our data is presented in table 3. Although in this study we only determined mRNA levels, it has been reported that for the majority of genes the mRNA levels reflect protein abundance very well $[38,39]$. We therefore allow ourselves to speculate about the functional consequences of nutritional PPAR $\alpha$ activation. Nevertheless, these implications should ultimately be evaluated in follow-up studies.

\section{Role of PPAR $\alpha$ in intestinal fatty acid oxidation}

It is well established that PPAR $\alpha$ serves as a master regulator of fatty acid catabolism, which is also apparent from our data [22,40]. Various transporters and phase I enzymes involved in fatty acid uptake and oxidation were PPAR $\alpha$-dependently regulated (Table 3). Although the extent varied somewhat, all 4 agonists regulated long chain fatty acid uptake, mitochondrial and peroxisomal $\beta$ oxidation, $\omega$-oxidation, and the metabolism of energyyielding substrates (glycogenolysis and Krebs cycle). For most genes this regulation was agonist-independent and is consistent with earlier findings [41-43]. It is known that enhanced fatty acid $\beta$-oxidation is correlated with reduced severity of inflammatory bowel disease [44]. Furthermore it has been shown that WY14643 treatment caused a reduction of colon injury in a murine DNBS experimental colitis model [45] and that WY14643 treatment might have an anti-inflammatory effect in the small intestine [22]. It has been reported that the expression of Octn2 (Slc22a5), involved in apical carnitine uptake, is induced by WY14643 and clofibrate [46-48]. Here we showed that also EPA and DHA induced expression of Octn2. Recently it has been reported that two functionally relevant polymorphisms in the Octn2 (Slc22a5) gene are associated with increased risk for inflammatory bowel disease $[49,50]$, and that Octn2 expression is decreased in rats with induced inflammatory bowel disease [51]. Taken together, our data imply that nutritional activation of PPAR $\alpha$ might be therapeutically valuable for patients with inflammatory bowel disease.

Table 2: Confirmation of microarray results

\begin{tabular}{|c|c|c|c|c|c|c|c|c|}
\hline \multirow[b]{2}{*}{ Gene symbol } & \multicolumn{2}{|c|}{ WYI4643 } & \multicolumn{2}{|c|}{ EPA } & \multicolumn{2}{|c|}{ DHA } & \multicolumn{2}{|c|}{ OA } \\
\hline & FC (MA) & $F C$ (qPCR) & FC (MA) & $F C$ (qPCR) & FC (MA) & $F C$ (qPCR) & FC (MA) & $F C$ (qPCR) \\
\hline Fatp4 (Slc27a4) & I.7 (0.24) & $2.2(0.28)^{*}$ & $\mathrm{I} .5(0.14)$ & $1.7(0.30)^{*}$ & $1.4(0.14)$ & I.5 (0.09)* & $1.4(0.16)$ & $1.6(0.4 I)^{*}$ \\
\hline$A b c d 3$ & $2.8(0.38)$ & $4.9(0.75)^{*}$ & $1.7(0.11)$ & $2.0(0.28)^{*}$ & $1.8(0.08)$ & $2.7(0.50)^{*}$ & $1.4(0.10)$ & $2.0(0.22)^{*}$ \\
\hline Сур2c65 & $2.6(0.34)$ & $3.7(0.69)^{*}$ & $2.3(0.24)$ & $2.8(0.5 \mathrm{I})^{*}$ & $2.5(0.48)$ & $3.9(1.13)^{*}$ & $1.7(0.23)$ & $2.7(0.94)^{*}$ \\
\hline Сур4FI6 & $1.9(0.36)$ & $2.0(0.44)^{*}$ & $1.5(0.14)$ & $1.3(0.30)^{*}$ & $1.4(0.17)$ & $1.5(0.25)^{*}$ & $1.9(0.34)$ & $2.5(0.36)^{*}$ \\
\hline
\end{tabular}

Microarray results were confirmed with qPCR. FC = Fold change, $M A=$ microarray, $q P C R=$ quantitative PCR. For the qPCR analysis: $m R N A$ levels were standardized to cyclophilin; expression in the PPAR $\alpha$-null mice was arbitrarily set to I. Significance was determined by a Bayesian t-test (array data) or unpaired student's $t$-test ( $q$ PCR data), $*=p$-value $<0.05$. Data are means \pm standard error $(n=4-5)$. 
A

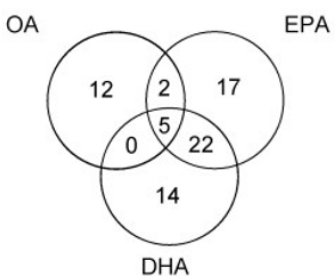

B

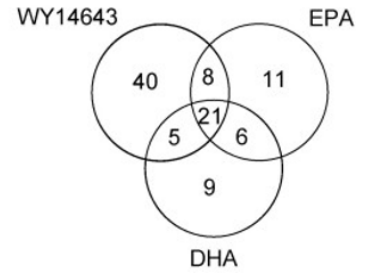

Figure I

Overlap of PPAR $\alpha$-dependently regulated genes between the four agonists. The numbers in the Venn plots represent the numbers of PPAR $\alpha$-dependently regulated genes for each treatment. A) Overlap between OA, EPA and DHA, B) Overlap between EPA, DHA, and WYI4643.

\section{PPAR $\alpha$ regulates intestinal cholesterol flux}

Expression of the apical cholesterol uptake transporter Npc1l1 was PPAR $\alpha$-dependently suppressed after treatment with WY14643, EPA, and DHA (Table 3), as also has been observed after fenofibrate treatment [52] and PPAR $\delta$ activation [53]. It is known that treatment with WY14643 for 5 days induced expression of Abca1 [54]. Here we show that Abca1 is also acutely regulated after PPAR $\alpha$ activation. Abca1, which promotes cholesterol efflux at the basolateral membrane to Apo-AI for HDL formation [5558] was increased after treatment with WY14643 and EPA. Functionally these results suggest that less cholesterol is absorbed from the lumen and more cholesterol is transferred to Apo-A1, resulting in reduced intracellular cholesterol levels in enterocytes. Enterocytes likely compensate for this by increasing the activity of HMG-CoA reductase, as has been reported before [59-61].

\section{PPAR $\alpha$ regulates intestinal nutrient transport and metabolism}

Expression of the apical glucose uptake transporter Sglt1 (Slc5a1) and the basolateral glucose efflux transporter Glut2 (Slc2a2) was PPAR $\alpha$-dependently repressed after WY14643 treatment. Furthermore, WY14643, EPA, and DHA all reduced expression of the apical mannose and glucose uptake transporter Sglt4 (Slc5a9), suggesting that PPAR $\alpha$ activation results in reduced glucose transport through the intestinal wall. In addition, several transporters involved in the amino acid metabolism were PPAR $\alpha$ dependently regulated (Table 3 ). Gene expression of small intestinal apical uptake as well as basolateral efflux amino acid transporters was PPAR $\alpha$-dependently suppressed. Furthermore, activation of PPAR $\alpha$ reduced expression of Slc25a12 (Aralar1), which is involved in the malate-aspartate shuttle [62]. These effects are in line with data that showed PPAR $\alpha$-mediated downregulation of genes involved in hepatic amino acid metabolism $[40,63]$. For liver it is suggested that amino acids are con-

served for local synthetic processes, including protein and purine synthesis during for instance proliferation [64]. In the small intestine villus length is increased after WY14643 treatment [22], which implies that also in the small intestine amino acids are conserved for local anabolic processes. Taken together, our results suggest that PPAR $\alpha$ activation leads to a diminished (neutral) amino acid flux through the enterocyte.

\section{PPAR $\alpha$ regulates intestinal motility}

Expression of the serotonin transporter Slc6a4 (Sert) was decreased after treatment with WY14643, EPA, and DHA (Table 3). Serotonin is a neurotransmitter secreted by enterochromaffin cells and is considered to play a key role in functioning of the gut, initiating peristaltic reflex pathways and facilitating propulsive activity [65].

Inactivation of serotonin is crucial to limit its activity, and this is mediated by Sert [66]. The observed reduced expression will result in a diminished activity of Sert, which in turn may increase intestinal motility [66]. Serotonin is detoxified by sulfation inside the enterocyte [67]. The apical sulfate import seems to be reduced as gene expression of the uptake transporter Slc13a1 (Nas1) was decreased. This might be a response to the decreased uptake of serotonin. We also showed that the dopamine transporter Dat 1 was PPAR $\alpha$-dependently upregulated after EPA and OA treatment (Table 4). Dopamine increases contractile force of intestinal motility [68], thus more dopamine likely results in increased intestinal motility. Altogether, we believe it is likely that PPAR $\alpha$ is involved in regulating intestinal motility. Our data suggest that in feeding conditions PPAR $\alpha$ activation may result in speeding-up intestinal motility.

\section{PPAR $\alpha$ diminishes effects of oxidative stress}

Oxidative stress results from an imbalance between formation and degradation of pro-oxidants or decreased cellular antioxidant protection mechanisms and may result in increased cell damage and apoptosis [69]. Many genes included in our barrier gene set, such as CypP450s, Gsts, and several Slc transporters, are involved in oxidative stress and were PPAR $\alpha$-dependently regulated. CypP450s induce oxidative stress by oxidative, peroxidative, and reductive metabolism of endogenous compounds and drugs [5], whereas Gsts are involved in the defense against oxidative stress by catalyzing the conjugation of glutathione to a wide variety of endogenous and exogenous electrophilic compounds [70]. Various CypP450 genes were PPAR $\alpha$-dependently upregulated (Table 4), which is in line with data obtained from liver [40]. However, since not all CypP450 genes are expressed in both organs, the regulated genes were not identical. Many Gsts were upregulated by activation with WY14643, EPA, and DHA (Table 3 ). In addition, various Slc transporters involved in oxida- 
Table 3: Overview of regulated processes

\begin{tabular}{|c|c|c|c|c|c|c|}
\hline Gene symbol & Probeset ID & FC WY & FC EPA & FC DHA & FC OA & Function \\
\hline \multicolumn{7}{|c|}{ Fatty acid oxidation } \\
\hline Fatp4 (Slc27a4) & |42444|_at & 1.7 & 1.5 & 1.4 & 1.4 & Apical long chain FA uptake [76] \\
\hline Cact (Slc25a20) & 1423109_s_at & 6.8 & 2.6 & 2.4 & $\mathrm{nc}$ & Carnitine cycle in mitochondrial $\beta$-oxidation [62] \\
\hline Octn2 (Slc22a5) & |421848_at & 7.7 & 3.2 & 4.2 & $\mathrm{nc}$ & Apical carnitine uptake for mitochondrial $\beta$-oxidation [48] \\
\hline Fatp2 (Slc27a2) & 1416316_at & 2.2 & 1.6 & nc & $\mathrm{nc}$ & $\begin{array}{l}\text { Has acyl CoA properties to activate FA for subsequent } \\
\text { peroxisomal } \beta \text {-oxidation [86] }\end{array}$ \\
\hline Abcd3 & 1416679_at & 2.8 & 1.7 & 1.8 & 1.4 & $\begin{array}{l}\text { Transport of VLFA over the peroxisomal membrane for } \\
\text { peroxisomal } \beta \text {-oxidation [77] }\end{array}$ \\
\hline Cyp4al0 & |424853_s_at & 1447.2 & 120.2 & 160.3 & $\mathrm{nc}$ & $\omega$-oxidation [87] \\
\hline Cyp4bI & 1416194_at & 1.7 & $\mathrm{nc}$ & nc & $\mathrm{nc}$ & $\omega$-oxidation $[87,88]$ \\
\hline Cyp4fl 6 & 1417277_at & 1.9 & 1.5 & 1.4 & 1.9 & $\omega$-oxidation $[89,90]$ \\
\hline G6ptl (Slc37a4) & 1417042_at & -1.5 & $\mathrm{nc}$ & $\mathrm{nc}$ & $\mathrm{nc}$ & Glycogenolysis [91] \\
\hline Nadcl (Slcl3a2) & |4|8857_at & -2.1 & -2.2 & $\mathrm{nc}$ & $\mathrm{nc}$ & Dicarboxylates uptake for Krebs cycle [92] \\
\hline \multicolumn{7}{|l|}{ Cholesterol flux } \\
\hline Npclll & |4385|4_at & -1.5 & -1.4 & -1.6 & $\mathrm{nc}$ & Apical cholesterol uptake [93] \\
\hline Abcal & 1450392_at & 12.1 & 3.2 & nc & $\mathrm{nc}$ & Basolateral cholesterol efflux $[56,58]$ \\
\hline \multicolumn{7}{|c|}{ Glucose transport } \\
\hline Sglt l (Slc5al) & |45543|_at & -1.4 & $\mathrm{nc}$ & $\mathrm{nc}$ & $\mathrm{nc}$ & Apical glucose uptake [94] \\
\hline Glut2 (Slc2a2) & 1449067_at & -1.4 & $\mathrm{nc}$ & $\mathrm{nc}$ & $\mathrm{nc}$ & Basolateral glucose efflux [95] \\
\hline Glutl (Slc2al) & 1426599_a_at & -1.5 & $\mathrm{nc}$ & $\mathrm{nc}$ & $\mathrm{nc}$ & Glucose transport [95] \\
\hline Sglt4 (Slc5a9) & |439494_at & -1.7 & -1.7 & -2.0 & $\mathrm{nc}$ & Glucose + mannose transport [96] \\
\hline \multicolumn{7}{|c|}{ Amino acid metabolism } \\
\hline Eaacl (Slclal) & 1448299_at & -1.4 & $\mathrm{nc}$ & $\mathrm{nc}$ & $\mathrm{nc}$ & Apical glutamate uptake [97] \\
\hline Patl (Slc36al) & 1428793_at & $\mathrm{nc}$ & -1.6 & -1.8 & $\mathrm{nc}$ & Apical neutral amino acids uptake [98] \\
\hline Lat2 (Slc7a8) & 1417929_at & -1.6 & -1.6 & -2.0 & $\mathrm{nc}$ & Basolateral neutral amino acids efflux [99] \\
\hline Tatl (Slcl6al0) & 1436368_at & -1.7 & -1.4 & -1.8 & $\mathrm{nc}$ & Basolateral aromatic amino acids efflux [100] \\
\hline y+Latl (Slc7a7) & |447|8I_s_at & 1.5 & nc & $\mathrm{nc}$ & $\mathrm{nc}$ & Basolateral cationic amino acids efflux [99] \\
\hline Aralarl (SIc25a I2) & 1428440_at & -1.3 & $\mathrm{nc}$ & $\mathrm{nc}$ & $\mathrm{nc}$ & Malate-aspartate shuttle: provides cytosolic aspartate [62] \\
\hline \multicolumn{7}{|l|}{ Intestinal motility } \\
\hline Sert (Slc6a4) & 1417|50_at & -1.4 & -1.2 & -1.3 & $\mathrm{nc}$ & Serotonine uptake [66] \\
\hline Datl (Slc6a3) & 1417415_at & nc & 1.8 & nc & 2.6 & Dopamine uptake [68] \\
\hline Nasl (Slcl3al) & 1430804_at & -2.1 & -2.0 & $\mathrm{nc}$ & -2.3 & Apical sulphate uptake [I0I] \\
\hline \multicolumn{7}{|l|}{ Oxidative stress } \\
\hline $\operatorname{Dic}(\operatorname{Slc} 25 \mathrm{a} \mid 0)$ & 1416954_at & 1.6 & 1.5 & $\mathrm{nc}$ & $\mathrm{nc}$ & Pyruvate metabolism [62] \\
\hline Kmcpl (Slc25a30) & 1420836_at & 5.5 & $\mathrm{nc}$ & $\mathrm{nc}$ & $\mathrm{nc}$ & $?$ \\
\hline $\operatorname{Mct} 3$ (SIcl6al3) & 1453056_at & 10.7 & 1.5 & 1.8 & $\mathrm{nc}$ & ? \\
\hline Svctl (Slc23al) & 1421912_at & $\mathrm{nc}$ & 1.7 & $\mathrm{nc}$ & $\mathrm{nc}$ & Apical vitamin C uptake [102] \\
\hline Svct2 (Slc23a2) & 1445589_at & 1.4 & $\mathrm{nc}$ & $\mathrm{nc}$ & $\mathrm{nc}$ & Basolateral vitamin C uptake [102] \\
\hline Сур2с29 & |41765|_at & $\mathrm{nc}$ & 3.2 & $\mathrm{nc}$ & $\mathrm{nc}$ & Phase I metabolism \\
\hline Сур2c65 & 1429994_s_at & 2.6 & 2.3 & 2.5 & 1.7 & Phase I metabolism \\
\hline Сур2d22 & 1419039_at & 1.7 & 1.5 & $\mathrm{nc}$ & $\mathrm{nc}$ & Phase I metabolism \\
\hline Akrlb8 & |448894_at & 13.4 & 3.2 & 5.1 & $\mathrm{nc}$ & ? \\
\hline Akrlcl2 & 1422000_at & -1.5 & $\mathrm{nc}$ & $\mathrm{nc}$ & $\mathrm{nc}$ & Aldo-ketoreductase activity (Phase II) \\
\hline Akrlcl3 & 1418672_at & -1.7 & $\mathrm{nc}$ & $\mathrm{nc}$ & $\mathrm{nc}$ & Aldo-ketoreductase activity (Phase II) \\
\hline EphxI & 1422438_at & 1.7 & 1.6 & 1.9 & nc & Epoxide hydrolase activity (Phase II) \\
\hline Eph×2 & |448499_a_at & 1.5 & 1.4 & $\mathrm{nc}$ & $\mathrm{nc}$ & Epoxide hydrolase activity (Phase II) \\
\hline Gsta I///Gsta2 & |42104|_s_at & $\mathrm{nc}$ & 1.2 & 1.3 & $\mathrm{nc}$ & Glutathione transferase activity (phase II) \\
\hline Gsta3 & 1423436_at & $\mathrm{nc}$ & $\mathrm{nc}$ & 1.8 & $\mathrm{nc}$ & Glutathione transferase activity (phase II) \\
\hline Gsta4 & 1416368_at & $\mathrm{nc}$ & $\mathrm{nc}$ & 1.5 & $\mathrm{nc}$ & Glutathione transferase activity (phase II) \\
\hline Gstk I & 1452823_at & 1.3 & 1.3 & 1.5 & $\mathrm{nc}$ & Glutathione transferase activity (phase II) \\
\hline Gstm I & 1448330_at & $\mathrm{nc}$ & 1.7 & nc & $\mathrm{nc}$ & Glutathione transferase activity (phase II) \\
\hline Gstm3 & 1427473_at & $\mathrm{nc}$ & 2.4 & 2.6 & $\mathrm{nc}$ & Glutathione transferase activity (phase II) \\
\hline Gstm4 & 1424835_at & 2.0 & 1.8 & 1.8 & $\mathrm{nc}$ & Glutathione transferase activity (phase II) \\
\hline Gstm5 & 1416842_at & -1.3 & $\mathrm{nc}$ & $\mathrm{nc}$ & $\mathrm{nc}$ & Glutathione transferase activity (phase II) \\
\hline Gstm6 & 1422072_a_at & $\mathrm{nc}$ & 1.3 & $\mathrm{nc}$ & $\mathrm{nc}$ & Glutathione transferase activity (phase II) \\
\hline Gstt2 & 1417883_at & 1.2 & nc & $\mathrm{nc}$ & $\mathrm{nc}$ & Glutathione transferase activity (phase II) \\
\hline Mgst I & 14I5897_a_at & 1.4 & 1.3 & 1.2 & $\mathrm{nc}$ & Glutathione transferase activity (phase II) \\
\hline Abcg2 & 1422906_at & 1.9 & $\mathrm{nc}$ & 1.3 & $\mathrm{nc}$ & Apical heme secretion [74] \\
\hline
\end{tabular}

Overview of PPAR $\alpha$-dependently regulated processes related to transport and phase I/II metabolism in the small intestine. All processes are described in the results and discussion section. $\mathrm{FC}=$ fold change, $\mathrm{nc}=$ not changed. 
tive stress defense were PPAR $\alpha$-dependently upregulated; Dic (Slc25a10), involved in the pyruvate-malate shuttle, citrate-pyruvate shuttle, and gluconeogenesis from pyruvate, is known to protect against oxidative stress [62]; Svct2 (Slc23a2), a basolaterally-located uptake transporter for ascorbic acid [71]; Mct13 (Slc16a13), proposed to play an important role in communicating information on the redox state between cells [72]; Abcg2 (Bcrp1), a secretion transporter of heme and porphyrins located in the apical membrane [73,74]; and Kmcp1 (Slc25a30), probably involved in protection from oxidative damage in situations of increased mitochondrial metabolism [75]. Taken together, we show that many barrier genes involved in defense against oxidative stress were PPAR $\alpha$-dependently upregulated. These data point towards an important role of PPAR $\alpha$ in the defense against oxidative stress. In general oxidative stress results in increased cell damage and apoptosis [69] and our data might explain one of the mechanisms by which WY14643 suppresses many genes involved in apoptosis in the small intestine [22].

\section{Longitudinal distribution of the transcriptional regulation during PPAR $\alpha$ activation is not the same for PPAR $\alpha$ - dependently regulated genes}

Finally we investigated the expression along the proximaldistal axis of PPAR $\alpha$ and 4 genes that were PPAR $\alpha$ dependently regulated by all agonists (Figures 2 and 3). Expression was measured with qRT-PCR. For this analysis, the small intestine was divided in 10 equal parts; part 1 represents the proximal side, whereas part 10 represents the most distal end. Expression of PPAR $\alpha$ was maximal in duodenum and jejunum, and then gradually declined in ileum, both under basal conditions and after acute activation with WY14643 (Figure 2). For all treatments only the expression pattern in treated wild-type and PPAR $\alpha$-null mice of the 4 genes is reported (Figure 3). Fatp4, Abcd3, Cyp2c65, and Cyp4f16 are all involved in fatty acid metabolism; Fatp4 mediates the apical uptake of long chain fatty acids [76], whereas Abcd3 is involved in the peroxisomal $\beta$-oxidation of long chain fatty acids [77]. The human homolog of Cyp2c65 (CYP2C8) metabolizes arachidonic acid and generates epoxygenase products [78]. The rat homolog of Cyp4F16 (Cyp4F5) is involved in $\omega$-oxidation of prostaglandins [79].

In EPA-, DHA- and WY14643-treated mice we observed a similar expression pattern of Fatp4 (Figure 3A), which closely resembled that of PPAR $\alpha$ under control and WY14643-activated conditions. In contrast, OA-treated wild-type mice did not show this pattern. In all treatments no significant PPAR $\alpha$-dependent induction of Fatp4 was observed in the distal part of the small intestine. Abcd3 was uniformly induced by all treatments (Figure 3B). Activation with WY14643 revealed a robust, equal induction in all segments in wild-type compared to PPAR $\alpha$-null

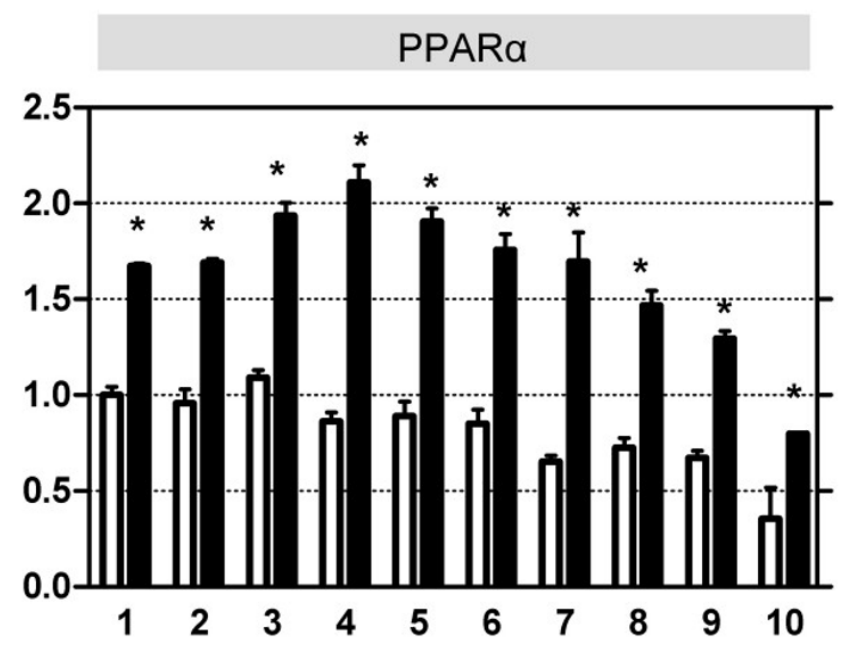

Figure 2

Expression of PPAR $\alpha$ along the longitudinal axis of control and WY I 4643-treated wild-type mice. QPCR was used to determine the relative expression levels of PPAR $\alpha$ in sections isolated along the proximal-distal axis of the small intestine of wild-type mice that received the control diet (white, open bars), or were acutely treated (6 hr) with WYI4643 (black, closed bars) ( $n=4$ per group). Small intestines were divided into 10 equal parts; part I refers to the most proximal part (duodenum), part 10 refers to the most distal (terminal ileum). Messenger RNA levels were standardized to cyclophilin; part I of the non-treated mice was arbitrarily set to I. Significance of control versus treated wild-type mice was determined per segment using an unpaired student's $t$-test. * $p$-value $<0.05$. Data are presented as mean \pm standard error.

mice, whereas these were less for the three natural agonists. Cyp2c65 was predominantly expressed in the proximal part of the small intestine, and showed high similarity between agonists (Figure 3C). For each agonist we observed an induction of its expression which was equal along the complete longitudinal axis. Cyp4F16 was uniformly expressed along the proximal-distal axis in treated PPAR $\alpha$-null mice (Figure 3D). However, treatment of wild-type mice with WY14643 and OA shifted the expression of Cyp4F16 to more distal regions, whereas EPA and DHA treatment resulted in significant increased expression in more proximal segments.

Taken together, the data in Figure 3 show that in general all agonists provoke a similar effect on expression of 4 PPAR $\alpha$-dependently regulated genes, and this induction also occurs in more distally-located cells. The latter demonstrates that despite its relatively low expression, PPAR $\alpha$ is still able to regulate gene expression. 
A
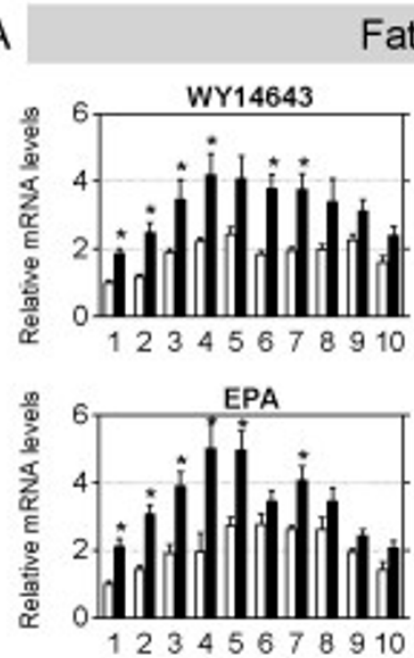

B

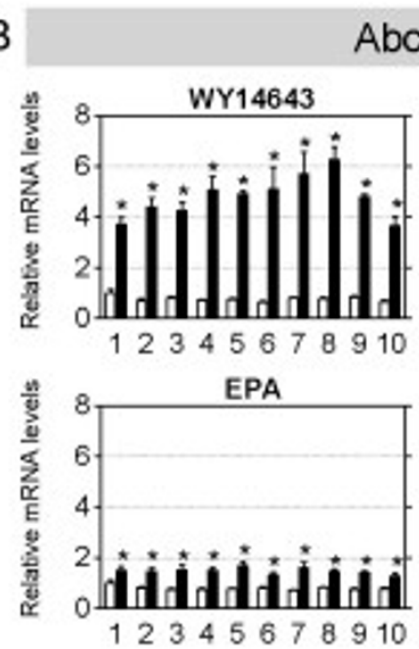

Fatp4

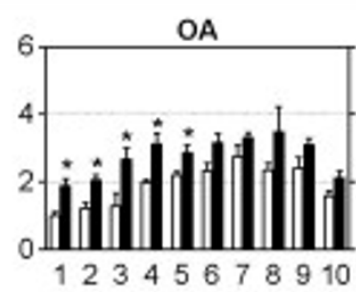

DHA

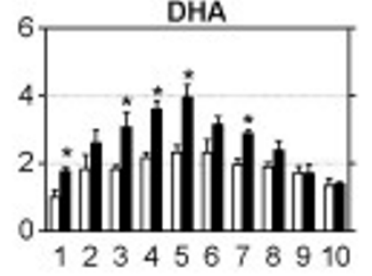

C

Cyp2c65
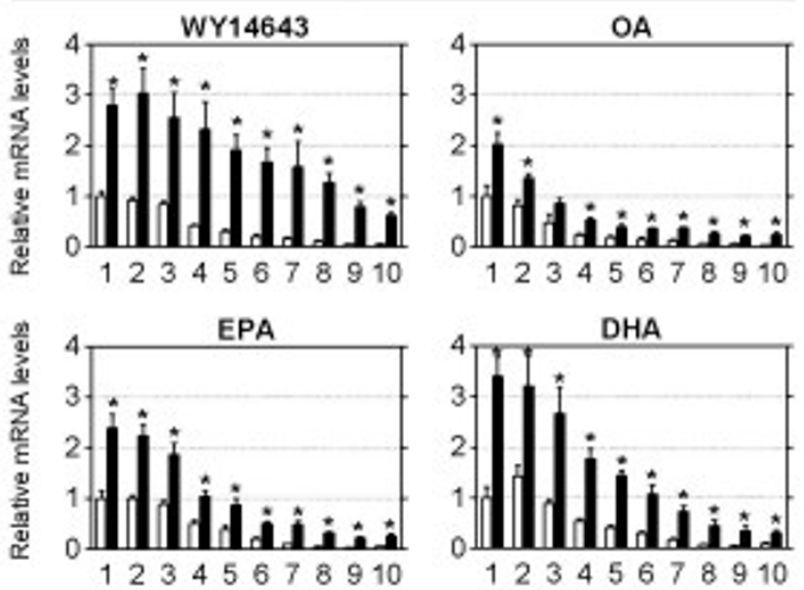

$\mathrm{D}$
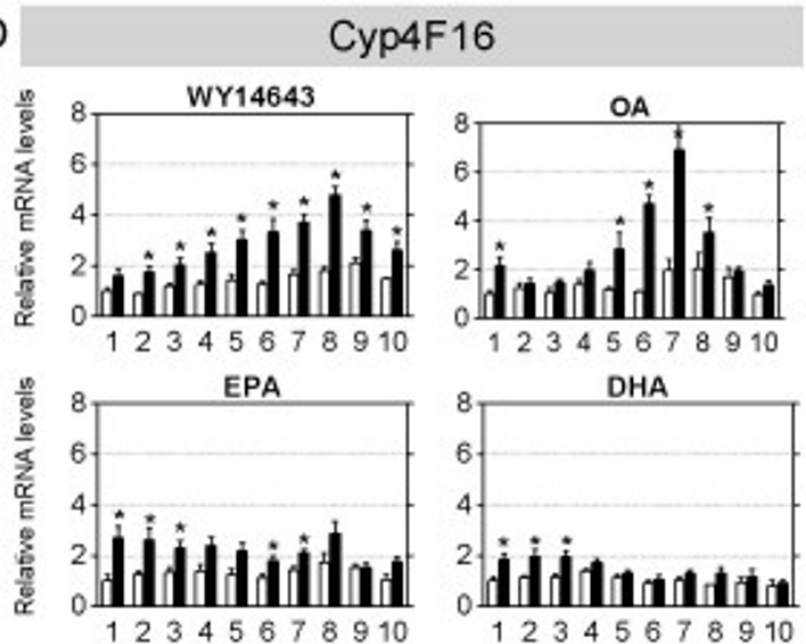

Figure 3

Expression of PPAR $\alpha$-dependently regulated genes along the longitudinal axis of treated PPAR $\alpha$-null and wild-type mice. QPCR was used to determine relative expression levels of PPAR $\alpha$-dependently regulated genes in sections isolated along the proximal-distal axis of the small intestine from PPAR $\alpha$-null mice (white, open bars) and wild-type mice (black, closed bars) that were acutely treated $(6 \mathrm{hr})$ with the 4 agonists $(n=4$ per group). The small intestine was divided into 10 equal parts; part I refers to the most proximal part (duodenum), part 10 refers to the most distal (terminal ileum). Messenger RNA levels were standardized to cyclophilin; part I of the PPAR $\alpha$-null mice was arbitrarily set to I. White bars represent the PPAR $\alpha$-null mice, black bars represent the wild-type mice. Significance of treated WT versus treated KO mice was determined per segment using an unpaired student's $t$-test. ${ }^{*} p$-value $<0.05$. Data are presented as mean \pm standard error. A) fatty acid transport protein 4 (Fatp4). B) ATP-binding cassette, sub-family D, member 3 (Abcd3; ALD). C) cytochrome P450, family 2, subfamily c, polypeptide 65 (Cyp2c65). D) cytochrome P450, family 4, subfamily f, polypeptide 16 (Cyp4fI6).

\section{Conclusion}

In the current study we have identified intestinal barrier genes that were PPAR $\alpha$-dependently regulated after acute activation by fatty acids. The functional outcomes inferred from our data suggest that nutritional-activated PPAR $\alpha$ controls processes ranging from fatty acid oxidation and cholesterol-, glucose-, and amino acid-transport and metabolism to intestinal motility and oxidative stress. Altogether, we showed that PPAR $\alpha$ has a great impact in controlling the barrier function of the gut, and this under- scores the importance of PPAR $\alpha$ for nutrient-mediated gene regulation in intestine.

\section{Methods}

\section{Animals and materials}

Pure bred wild-type (129S1/SvImJ) and Ppara-null (129S4/SvJae) mice [80] were bred and housed as described [81]. All animal studies were approved by the Local Committee for Care and Use of Laboratory Animals. The synthetic triacylglycerols trieicosapentaenoin and tridocosahexaenoin were bought from Nu-Chek-Prep, Inc 
(Elysian, MN), whereas triolein was from Fluka (Zwijndrecht, the Netherlands). These are synthetic triacylglycerols with three identical acyl moieties, namely eicosapentaenoic acid (EPA), docosahexanoic acid (DHA) and oleic acid (OA), which are released as free fatty acids upon digestion in the small intestinal lumen. All three fatty acids have been reported to bind PPAR $\alpha$ with varying affinities in the micromolar range [30-33]. WY14643 was obtained from Chemsyn (Lenexa, KS).

\section{Experimental design and tissue handling}

Four months-old male wild-type and PPAR $\alpha$-null mice were used in this study ( $\mathrm{n}=4-5$ per group). Two weeks before the start of the experiment all mice were put on a background diet, which was a modified AIN76A diet (Research diet services, Wijk bij Duurstede, The Netherlands). The AIN76A diet contains 5\% w/w corn oil ( 10 energy\%) [82], which is a relatively low amount of fat. In the current study we replaced the corn oil by the same amount of olive oil (predominantly consisting of oleic acid), since Ren et al [83] demonstrated that an olive oilrich diet did not regulate established PPAR $\alpha$ target genes. The modified AIN76A diet was thus assumed to be a 'poor PPAR $\alpha$-activating' diet, and therefore we hypothesized the number of genes PPAR $\alpha$-dependently regulated by OA would be nominal. However, since the amount of OA in the diet was lower than the amount dosed by gavage (see below), some genes were expected to be regulated.

At the day of the experiment mice were fasted for four hours. At 9 AM mice were dosed by oral gavage with 400 $\mu \mathrm{l}$ of the synthetic triacylglycerols triolein, trieicosapentaenoin, or tridocosahexaenoin, or $400 \mu \mathrm{l}$ of a $0.1 \%$ WY14643 suspension in $0.5 \%$ carboxymethyl cellulose (Sigma-Aldrich, Zwijndrecht, the Netherlands). The volume of all doses $(400 \mu \mathrm{l})$ equalled the maximum recommended volume for gastric gavages for mice [84]. For the fatty acids these doses corresponded to approximately $12.5 \mathrm{~g} / \mathrm{kg}$ body weight. To put this amount into perspective, data on food intake (not shown) revealed that the mice consumed approximately 4 gram of the modified AIN76A diet per day, which corresponds to approximately $200 \mathrm{mg}(6.7 \mathrm{~g} / \mathrm{kg}$ body weight $)$ of fat. The amount of WY14643 the mice received (approximately $130 \mathrm{mg} / \mathrm{kg}$ body weight) was based on previously published shortterm study [85].

Six hours after the gavage the mice were anaesthetized with a mixture of isofluorane $(1.5 \%)$, nitrous oxide $(70 \%)$ and oxygen $(30 \%)$. Small intestines were isolated and flushed with ice-cold phosphate-buffer saline and subsequent tissue handlings were performed on ice. Remaining fat and pancreatic tissue was carefully removed from the intestines. For RNA analyses of total tissue, we used fulllength small intestine (microarray analyses), or sections obtained after dividing the small intestine into 10 equal parts (studying gene expression distribution along the proximal-distal axis). All small intestinal samples were snap-frozen in liquid nitrogen and stored at $-80^{\circ} \mathrm{C}$ until RNA isolation.

\section{RNA isolation, Affymetrix GeneChip oligoarray hybridization and scanning, and quantitative real-time PCR}

RNA isolation, Affymetrix GeneChip oligoarray hybridization and scanning, and quantitative real-time PCR were performed as described previously [81]. The sequences of primers used in qRT-PCR are available on request. For microarray analyses, RNA was isolated from the fulllength small intestine. RNA was hybridized on an Affymetrix GeneChip Mouse Genome 4302.0 array. This array detects 45,038 transcripts that represent 16,579 known genes. For each experimental group, four or five biological replicates were hybridized for wild-type and PPAR $\alpha$-null mice, and in total 35 arrays were used. Array data have been submitted to the Gene Expression Omnibus, accession number GSE9533.

\section{Analyses of microarray data}

Microarrays were analyzed as described previously [81]. To compile a list of transport and phase I/II metabolism (barrier) genes represented on the array, annotation information from Affymetrix (release of July 2006) was queried for SLC transporters, ABC transporters, CypP450s, the phase II metabolism enzymes glutathione S-transferases, sulfotransferases, epoxide hydrolases, aldo-keto reductases, $\mathrm{N}$-acetyltransferases, and glucuronosyl transferases. Also glutathione reductase, glutathione synthetase, and glutathione peroxidases were included in this set. The final set consisted of 944 probesets, encoding for 529 unique genes. To study significantly expressed genes, only probesets with an expression estimate higher than 32 in either of the 8 experimental groups were selected for further analysis. This cut-off value was based GPCR experiments, because regulation of genes with an expression estimate $>32$ on the array could all be confirmed by qPCR [81]. The filtering was done after normalization and data analysis. Probesets that had a Bayesian comparison pvalue $<0.01$ were considered to be significantly regulated; no cut-off value of the fold change was used. Of these, probesets that were changed in treated wild-type mice compared to treated PPAR $\alpha$-null mice, were designated PPAR $\alpha$-dependently regulated. QPCR data confirming our array analysis is presented in Table 2 and additional data, Table 7. Differences on the number of regulated genes between gene sets were tested for significance by a one-tailed binominal test. Interpretations of functional outcomes focused on groups of genes that are known to be functionally related (i.e. having a similar function or participating in the same pathway). 


\section{Authors' contributions}

MM and GH conceived the study and supervised its design and coordination. The design of the study was set up by $\mathrm{HdV}$ and $\mathrm{MB}$. HdV, MB, HB and $\mathrm{GH}$ were involved in experimental work. Microarray analysis was performed by HdV, PdG and GH. HdV drafted the manuscript and GH and MM participated in its preparation. All authors have read and approved the final manuscript.

\section{Additional material}

\section{Additional file 1}

PPAR $\alpha$-dependently regulated barrier genes upon WY14643 treatment. Click here for file

[http://www.biomedcentral.com/content/supplementary/14712164-9-231-S1.pdf]

\section{Additional file 2}

PPAR $\alpha$-dependently regulated barrier genes upon OA treatment. Click here for file

[http://www.biomedcentral.com/content/supplementary/1471-

2164-9-231-S2.pdf]

\section{Additional file 3}

PPAR $\alpha$-dependently regulated barrier genes upon EPA treatment. Click here for file

[http://www.biomedcentral.com/content/supplementary/1471-

2164-9-231-S3.pdf]

\section{Additional file 4}

PPAR $\alpha$-dependently regulated barrier genes upon DHA treatment. Click here for file

[http://www.biomedcentral.com/content/supplementary/1471-

2164-9-231-S4.pdf]

\section{Additional file 5}

PPAR $\alpha$-dependently regulated barrier genes after acute $(6 \mathrm{hr})$ and longterm (5 day) treatment with WY14643.

Click here for file

[http://www.biomedcentral.com/content/supplementary/14712164-9-231-S5.pdf]

\section{Additional file 6}

Overlap of PPAR $\alpha$-dependently regulated barrier genes after acute treatment with WY14643, EPA, and DHA.

Click here for file

[http://www.biomedcentral.com/content/supplementary/14712164-9-231-S6.pdf]

\section{Additional file 7}

Additional confirmatory qPCR data.

Click here for file

[http://www.biomedcentral.com/content/supplementary/14712164-9-231-S7.pdf]

\section{Acknowledgements}

The authors thank Rene Bakker and Bert Weijers for excellent assistance with animal experiments, and Mechteld Grootte Bromhaar and Jenny
Jansen for expert microarray hybridizations. This study was partially supported by a grant of the Graduate School VLAG.

\section{References}

I. Hediger MA, Romero MF, Peng JB, Rolfs A, Takanaga H, Bruford EA: The ABCs of solute carriers: physiological, pathological and therapeutic implications of human membrane transport proteins. Pflugers Arch 2004, 447(5):465-468.

2. Borst P, Elferink RO: Mammalian ABC transporters in health and disease. Annu Rev Biochem 2002, 71:537-592.

3. Wacher VJ, Salphati L, Benet LZ: Active secretion and enterocytic drug metabolism barriers to drug absorption. Adv Drug Deliv Rev 200I, 46(I-3):89-102.

4. Kaminsky LS, Zhang QY: The small intestine as a xenobioticmetabolizing organ. Drug Metab Dispos 2003, 3 I ( I 2): I520-I525.

5. Danielson PB: The cytochrome $\mathbf{P 4 5 0}$ superfamily: biochemistry, evolution and drug metabolism in humans. Curr Drug Metab 2002, 3(6):56I-597.

6. Banoglu E: Current status of the cytosolic sulfotransferases in the metabolic activation of promutagens and procarcinogens. Curr Drug Metab 2000, I(I):I-30.

7. Weinshilboum RM, Otterness DM, Aksoy IA, Wood TC, Her C Raftogianis RB: Sulfation and sulfotransferases I: Sulfotransferase molecular biology: cDNAs and genes. FASEB J 1997, II(I):3-14

8. Tukey RH, Strassburg CP: Human UDP-Glucuronosyltransferases: Metabolism, Expression, and Disease. Annual Review of Pharmacology and Toxicology 2000, 40(I):58I-6I6.

9. Tew KD, Ronai Z: GST function in drug and stress response. Drug Resistance Updates 1999, 2(3): 143.

10. Moscow JA, Dixon KH: Glutathione-related enzymes, glutathione and multidrug resistance. Cytotechnology 1993, I2(I3): $155-170$.

II. Vatsis KP, Weber WW, Bell DA, Dupret JM, Evans DA, Grant DM, Hein DW, Lin HJ, Meyer UA, Relling MV, et al.: Nomenclature for $\mathrm{N}$-acetyltransferases. Pharmacogenetics 1995, 5(1):I-17.

12. Arand M, Cronin A, Adamska M, Oesch F: Epoxide hydrolases: structure, function, mechanism, and assay. Methods Enzymol 2005, 400:569-588.

13. Muller M, Kersten S: Nutrigenomics: goals and strategies. Nat Rev Genet 2003, 4(4):315-322

14. Desvergne B, Michalik L, Wahli W: Transcriptional regulation of metabolism. Physiol Rev 2006, 86(2):465-5I4.

15. Zhang Z, Burch PE, Cooney AJ, Lanz RB, Pereira FA, Wu J, Gibbs RA, Weinstock G, Wheeler DA: Genomic analysis of the nuclear receptor family: new insights into structure, regulation, and evolution from the rat genome. Genome Res 2004, I4(4):580-590.

16. Germain P, Staels B, Dacquet C, Spedding M, Laudet V: Overview of nomenclature of nuclear receptors. Pharmacol Rev 2006, 58(4):685-704.

17. Sampath $\mathrm{H}$, Ntambi JM: Polyunsaturated fatty acid regulation of genes of lipid metabolism. Annu Rev Nutr 2005, 25:3 17-340.

18. Desvergne B, Wahli W: Peroxisome proliferator-activated receptors: nuclear control of metabolism. EndocrRev 1999, 20(5):649-688.

19. Michalik L, Auwerx J, Berger JP, Chatterjee VK, Glass CK, Gonzalez FJ, Grimaldi PA, Kadowaki T, Lazar MA, O'Rahilly S, Palmer CN, Plutzky J, Reddy JK, Spiegelman BM, Staels B, Wahli W: International Union of Pharmacology. LXI. Peroxisome proliferator-activated receptors. Pharmacol Rev 2006, 58(4):726-74I.

20. Feige JN, Gelman L, Tudor C, Engelborghs Y, Wahli W, Desvergne B: Fluorescence imaging reveals the nuclear behavior of peroxisome proliferator-activated receptor/retinoid $X$ receptor heterodimers in the absence and presence of ligand. $J$ Biol Chem 2005, 280(18): I7880- 17890.

21. Ricote M, Glass CK: PPARs and molecular mechanisms of transrepression. Biochim Biophys Acta 2007, I 77 I (8):926-935.

22. Bünger $M$, van den Bosch HM, van der Meijde J, Kersten S, Hooiveld GJEJ, Müller M: Genome-wide analysis of PPARalpha activation in murine small intestine. Physiol Genomics 2007, 30(2): 192-204.

23. Kennedy ET, Bowman SA, Powell R: Dietary-fat intake in the US population. J Am Coll Nutr 1999, I 8(3):207-2I2. 
24. Phan CT, Tso P: Intestinal lipid absorption and transport. Front Biosci 200I, 6:D299-D319.

25. Kondo H, Minegishi Y, Komine Y, Mori T, Matsumoto I, Abe K, Tokimitsu I, Hase T, Murase T: Differential regulation of intestinal lipid metabolism-related genes in obesity-resistant $A / J$ vs. obesity-prone C57BL/6J mice. Am J Physiol Endocrinol Metab 2006, $291(5)$ :EI092-1099.

26. Fu J, Gaetani S, Oveisi F, Lo Verme J, Serrano A, Rodriguez De Fonseca F, Rosengarth A, Luecke H, Di Giacomo B, Tarzia G, Piomelli D: Oleylethanolamide regulates feeding and body weight through activation of the nuclear receptor PPAR-alpha. Nature 2003, 425(6953):90-93.

27. Murase T, Nagasawa A, Suzuki J, Wakisaka T, Hase T, Tokimitsu I: Dietary \{alpha\}-Linolenic Acid-Rich Diacylglycerols Reduce Body Weight Gain Accompanying the Stimulation of Intestinal \{beta\}-Oxidation and Related Gene Expressions in C57BL/Ks]-db/db Mice. J Nutr 2002, I 32( I 0):3018-3022.

28. Hirai T, Fukui $Y$, Motojima K: PPARalpha agonists positively and negatively regulate the expression of several nutrient/drug transporters in mouse small intestine. Biol Pharm Bull 2007, 30(I I):2185-2190.

29. Shimakura J, Terada T, Saito H, Katsura T, Inui K: Induction of intestinal peptide transporter I expression during fasting is mediated via peroxisome proliferator-activated receptor alpha. Am J Physiol Gastrointest Liver Physiol 2006, 29 I(5):G85I-6.

30. Forman BM, Chen J, Evans RM: Hypolipidemic drugs, polyunsaturated fatty acids, and eicosanoids are ligands for peroxisome proliferator-activated receptors alpha and delta. Proc Natl Acad Sci U S A 1997, 94(9):43 I 2-4317.

31. Kliewer SA, Sundseth SS, Jones SA, Brown PJ, Wisely GB, Koble CS, Devchand P, Wahli W, Willson TM, Lenhard JM, Lehmann JM: Fatty acids and eicosanoids regulate gene expression through direct interactions with peroxisome proliferator-activated receptors alpha and gamma. Proc Natl Acad Sci U S A 1997, 94(9):43 18-4323.

32. Krey G, Braissant O, L'Horset F, Kalkhoven E, Perroud M, Parker MG, Wahli W: Fatty acids, eicosanoids, and hypolipidemic agents identified as ligands of peroxisome proliferator-activated receptors by coactivator-dependent receptor ligand assay. Mol Endocrinol 1997, I I(6):779-79I.

33. Xu HE, Lambert MH, Montana VG, Parks DJ, Blanchard SG, Brown PJ, Sternbach DD, Lehmann JM, Wisely GB, Willson TM, Kliewer SA, Milburn MV: Molecular recognition of fatty acids by peroxisome proliferator-activated receptors. Mol Cell I999, 3(3):397-403.

34. Feige JN, Gelman L, Rossi D, Zoete V, Metivier R, Tudor C, Anghel SI, Grosdidier A, Lathion C, Engelborghs Y, Michielin O, Wahli W, Desvergne B: The Endocrine Disruptor Monoethyl-hexylphthalate Is a Selective Peroxisome Proliferator-activated Receptor \{gamma\} Modulator That Promotes Adipogenesis. J Biol Chem 2007, 282(26): 19152-19166.

35. Desvergne B, A IJ, Devchand PR, Wahli W: The peroxisome proliferator-activated receptors at the cross-road of diet and hormonal signalling. J Steroid Biochem Mol Biol 1998, 65(I6):65-74

36. Westin S, Kurokawa R, Nolte RT, Wisely GB, Mclnerney EM, Rose DW, Milburn MV, Rosenfeld MG, Glass CK: Interactions controlling the assembly of nuclear-receptor heterodimers and coactivators. Nature 1998, 395(6698): 199-202.

37. Nettles KW, Greene GL: Ligand control of coregulator recruitment to nuclear receptors. Annu Rev Physiol 2005, 67:309-333.

38. Kislinger T, Cox B, Kannan A, Chung C, Hu P, Ignatchenko A, Scott MS, Gramolini AO, Morris Q, Hallett MT, Rossant J, Hughes TR, Frey $B$, Emili $A$ : Global survey of organ and organelle protein expression in mouse: combined proteomic and transcriptomic profiling. Cell 2006, I 25(I): I73-186.

39. Cox B, Kislinger T, Wigle DA, Kannan A, Brown K, Okubo T, Hogan B, Jurisica I, Frey B, Rossant J, Emili A: Integrated proteomic and transcriptomic profiling of mouse lung development and Nmyc target genes. Mol Syst Biol 2007, 3:109.

40. Mandard S, Muller M, Kersten S: Peroxisome proliferator-activated receptor alpha target genes. Cell Mol Life Sci 2004, 6 I(4):393-4I6.

4I. Albet S, Causeret C, Bentejac M, Mandel JL, Aubourg P, Maurice B: Fenofibrate differently alters expression of genes encoding ATP-binding transporter proteins of the peroxisomal membrane. FEBS Lett 1997, 405(3):394-397.
42. Fourcade S, Savary S, Albet S, Gauthe D, Gondcaille C, Pineau T, Bellenger J, Bentejac M, Holzinger A, Berger J, Bugaut M: Fibrate induction of the adrenoleukodystrophy-related gene (ABCD2): promoter analysis and role of the peroxisome proliferatoractivated receptor PPARalpha. Eur J Biochem 200I, 268( I 2):3490-3500.

43. Patsouris D, Reddy JK, Muller M, Kersten S: Peroxisome proliferator-activated receptor alpha mediates the effects of highfat diet on hepatic gene expression. Endocrinology 2006, I47(3): |508-1516.

44. Roediger WE, Nance S: Metabolic induction of experimental ulcerative colitis by inhibition of fatty acid oxidation. $\mathrm{Br} J \operatorname{Exp}$ Pathol 1986, 67(6):773-782.

45. Cuzzocrea S, Di Paola R, Mazzon E, Genovese T, Muia C, Centorrino T, Caputi AP: Role of endogenous and exogenous ligands for the peroxisome proliferators activated receptors alpha (PPAR-alpha) in the development of inflammatory bowel disease in mice. Lab Invest 2004, 84( I 2): I 643-I 654.

46. van Vlies N, Ferdinandusse S, Turkenburg M, Wanders RJ, Vaz FM: PPAR alpha-activation results in enhanced carnitine biosynthesis and OCTN2-mediated hepatic carnitine accumulation. Biochim Biophys Acta 2007, I 767(9): I I34- I | 42.

47. Ringseis R, Posel S, Hirche F, Eder K: Treatment with pharmacological peroxisome proliferator-activated receptor alpha agonist clofibrate causes upregulation of organic cation transporter $\mathbf{2}$ in liver and small intestine of rats. Pharmacol Res 2007, 56(2): $175-183$.

48. Kato Y, Sugiura M, Sugiura T, Wakayama T, Kubo Y, Kobayashi D, Sai Y, Tamai I, Iseki S, Tsuji A: Organic Cation/Carnitine Transporter OCTN2 (SIc22a5) Is Responsible for Carnitine Transport across Apical Membranes of Small Intestinal Epithelial Cells in Mouse. Mol Pharmacol 2006, 70(3):829-837.

49. Waller S, Tremelling M, Bredin F, Godfrey L, Howson J, Parkes M: Evidence for association of OCTN genes and IBD5 with ulcerative colitis. Gut 2006, 55(6):809-8।4

50. Newman B, Gu X, Wintle R, Cescon D, Yazdanpanah M, Liu X, Peltekova $\mathrm{V}$, Van Oene $\mathrm{M}$, Amos $\mathrm{Cl}$, Siminovitch $\mathrm{KA}$ : A risk haplotype in the Solute Carrier Family 22A4/22A5 gene cluster influences phenotypic expression of Crohn's disease. Gastroenterology 2005, I 28(2):260-269.

5I. D'Argenio G, Calvani M, Casamassimi A, Petillo O, Margarucci S, Rienzo M, Peluso I, Calvani R, Ciccodicola A, Caporaso N, Peluso G: Experimental colitis: decreased Octn 2 and Atb0+ expression in rat colonocytes induces carnitine depletion that is reversible by carnitine-loaded liposomes. FASEB J 2006, 20( I 4):2544-2546.

52. Valasek MA, Clarke SL, Repa JJ: Fenofibrate reduces intestinal cholesterol absorption via PPARalpha -dependent modulation of NPCI LI expression in mouse. J Lipid Res 2007.

53. van der Veen JN, Kruit JK, Havinga R, Baller JFW, Chimini G, Lestavel S, Staels B, Groot PHE, Groen AK, Kuipers F: Reduced cholesterol absorption upon PPAR $\{$ delta\} activation coincides with decreased intestinal expression of NPCILI. J Lipid Res 2005, 46(3):526-534.

54. Knight BL, Patel DD, Humphreys SM, Wiggins D, Gibbons GF: Inhibition of cholesterol absorption associated with a PPAR alpha-dependent increase in ABC binding cassette transporter AI in mice. J Lipid Res 2003, 44(I I):2049-2058.

55. Murthy S, Born E, Mathur SN, Field FJ: LXR/RXR activation enhances basolateral efflux of cholesterol in CaCo-2 cells. J Lipid Res 2002, 43(7): 1054-1064.

56. Mulligan JD, Flowers MT, Tebon A, Bitgood J], Wellington C, Hayden MR, Attie AD: ABCAI Is Essential for Efficient Basolateral Cholesterol Efflux during the Absorption of Dietary Cholesterol in Chickens. J Biol Chem 2003, 278(I 5): I3356-I 3366.

57. Francis GA, Knopp RH, Oram JF: Defective removal of cellular cholesterol and phospholipids by apolipoprotein A-I in Tangier Disease. J Clin Invest 1995, 96( I):78-87.

58. Schmitz G, Langmann T: Structure, function and regulation of the ABCI gene product. Curr Opin Lipidol 200 I, I2(2): |29-|40.

59. Gebhard RL, Prigge WF: In vivo regulation of canine intestinal 3-hydroxy-3-methylglutaryl coenzyme A reductase by cholesterol, lipoprotein, and fatty acids. J Lipid Res 198I, 22(7): IIII-III8.

60. Stange EF, Suckling KE, Dietschy JM: Synthesis and coenzyme Adependent esterification of cholesterol in rat intestinal epi- 
thelium. Differences in cellular localization and mechanisms of regulation. J Biol Chem 1983, 258(2I): 12868-I2875.

61. Oku H, Sugano M: Dietary fat dependence of intestinal 3. hydroxy-3-methylglutaryl coenzyme A (HMG-CoA) reductase activity in rats. J Nutr 1985, I I 5(7):880-889.

62. Palmieri F: The mitochondrial transporter family (SLC25): physiological and pathological implications. Pflugers Arch 2004, 447(5):689-709.

63. Kersten S, Mandard S, Escher P, Gonzalez FJ, Tafuri S, Desvergne B, Wahli $W$ : The peroxisome proliferator-activated receptor alpha regulates amino acid metabolism. FASEB J 200I, I 5(I I): | 97|-1978.

64. Sheikh K, Camejo G, Lanne B, Halvarsson T, Landergren MR, Oakes ND: Beyond lipids, pharmacological PPAR\{alpha\} activation has important effects on amino acid metabolism as studied in the rat. Am J Physiol Endocrinol Metab 2007, 292(4):EI I 57-I I 65.

65. Lordal M, Wallen H, Hjemdahl P, Beck O, Hellstrom PM: Concentration-dependent stimulation of intestinal phase III of migrating motor complex by circulating serotonin in humans. Clin Sci (Lond) 1998, 94(6):663-670.

66. Martel F: Recent advances on the importance of the serotonin transporter SERT in the rat intestine. Pharmacol Res 2006 54(2):73-76

67. Liu MC, Sakakibara Y, Liu CC: Bacterial expression, purification, and characterization of a novel mouse sulfotransferase that catalyzes the sulfation of eicosanoids. Biochem Biophys Res Commun 1999, 254(I):65-69.

68. Walker JKL, Gainetdinov RR, Mangel AW, Caron MG, Shetzline MA Mice lacking the dopamine transporter display altered regulation of distal colonic motility. Am J Physiol Gastrointest Liver Physiol 2000, 279(2):G3II-3I8.

69. Lee $\mathrm{HC}$, Wei $\mathrm{YH}$ : Mitochondrial role in life and death of the cell. J Biomed Sci 2000, 7(I):2-15.

70. Townsend DM, Tew KD, Tapiero $\mathrm{H}$ : The importance of glutathione in human disease. Biomed Pharmacother 2003, 57(34): $145-155$.

71. Tariq SA: Role of ascorbic Acid in scavenging free radicals and lead toxicity from biosystems. Mol Biotechnol 2007, 37(I):62-65.

72. Halestrap AP, Meredith D: The SLCI 6 gene family-from monocarboxylate transporters (MCTs) to aromatic amino acid transporters and beyond. Pflugers Arch 2004, 447(5):619-628.

73. Jonker JW, Buitelaar M, Wagenaar E, Van Der Valk MA, Scheffer GL, Scheper RJ, Plosch T, Kuipers F, Oude Elferink RP, Rosing H, Beijnen $\mathrm{JH}$, Schinkel $\mathrm{AH}$ : The breast cancer resistance protein protects against a major chlorophyll-derived dietary phototoxin and protoporphyria. Proc Natl Acad Sci U S A 2002, 99(24): I5649-I5654.

74. Krishnamurthy P, Ross DD, Nakanishi T, Bailey-Dell K, Zhou S, Mercer KE, Sarkadi B, Sorrentino BP, Schuetz JD: The Stem Cell Marker Bcrp/ABCG2 Enhances Hypoxic Cell Survival through Interactions with Heme. I Biol Chem 2004, 279(23):242 18-24225.

75. Haguenauer A, Raimbault S, Masscheleyn S, del Mar Gonzalez-Barroso M, Criscuolo F, Plamondon J, Miroux B, Ricquier D, Richard D, Bouillaud F, Pecqueur C: A New Renal Mitochondrial Carrier, KMCPI, Is Up-regulated during Tubular Cell Regeneration and Induction of Antioxidant Enzymes. J Biol Chem 2005, 280(23):22036-22043.

76. Stahl A, Hirsch DJ, Gimeno RE, Punreddy S, Ge P, Watson N, Patel S, Kotler M, Raimondi A, Tartaglia LA, Lodish HF: Identification of the major intestinal fatty acid transport protein. Mol Cell 1999, 4(3):299-308.

77. Wanders RJ, Visser WF, van Roermund CW, Kemp S, Waterham HR: The peroxisomal ABC transporter family. Pflugers Arch 2007, 453(5):719-734.

78. Rifkind $A B$, Lee $C$, Chang TK, Waxman DJ: Arachidonic acid metabolism by human cytochrome P450s 2C8, 2C9, 2EI, and IA2: regioselective oxygenation and evidence for a role for CYP2C enzymes in arachidonic acid epoxygenation in human liver microsomes. Arch Biochem Biophys 1995 , 320(2):380-389.

79. Kawashima H, Kusunose E, Thompson CM, Strobel HW: Protein expression, characterization, and regulation of CYP4F4 and CYP4F5 cloned from rat brain. Arch Biochem Biophys 1997, 347(I): | $48-154$
80. Lee SS, Pineau T, Drago J, Lee El, Owens JW, Kroetz DL, FernandezSalguero PM, Westphal H, Gonzalez FJ: Targeted disruption of the alpha isoform of the peroxisome proliferator-activated receptor gene in mice results in abolishment of the pleiotropic effects of peroxisome proliferators. Mol Cell Biol 1995, I5(6):30|2-3022

8I. van den Bosch HM, Bünger M, de Groot PJ, van der Meijde J, Hooiveld GJEJ, Müller M: Gene expression of transporters and phase I/II metabolic enzymes in murine small intestine during fasting. BMC Genomics 2007, 8(I):267.

82. Bieri JG: Second Report of the Ad Hoc Committee on Standards for Nutritional Studies. J Nutr 1980, I I 0(8): 1726

83. Ren B, Thelen AP, Peters JM, Gonzalez FJ, Jump DB: Polyunsaturated fatty acid suppression of hepatic fatty acid synthase and $\mathrm{S} / 4$ gene expression does not require peroxisome proliferator-activated receptor alpha. I Biol Chem 1997, 272(43):26827-26832.

84. Diehl KH, Hull R, Morton D, Pfister R, Rabemampianina Y, Smith D Vidal JM, van de Vorstenbosch C: A good practice guide to the administration of substances and removal of blood, including routes and volumes. J Appl Toxicol 200I, 2I (I):15-23.

85. Compe E, Drane P, Laurent C, Diderich K, Braun C, Hoeijmakers JH, Egly JM: Dysregulation of the peroxisome proliferator-activated receptor target genes by XPD mutations. Mol Cell Biol 2005, 25(I 4):6065-6076.

86. Steinberg SJ, Wang SJ, Kim DG, Mihalik SJ, Watkins PA: Human very-long-chain acyl-CoA synthetase: cloning, topography, and relevance to branched-chain fatty acid metabolism. Biochem Biophys Res Commun 1999, 257(2):615-621.

87. Okita RT, Okita JR: Cytochrome P450 4A fatty acid omega hydroxylases. Curr Drug Metab 200I, 2(3):265-28I.

88. Fisher MB, Zheng YM, Rettie AE: Positional specificity of rabbit CYP4B I for omega-hydroxylation I of short-medium chain fatty acids and hydrocarbons. Biochem Biophys Res Commun 1998, 248(2):352-355.

89. Harmon SD, Fang X, Kaduce TL, Hu S, Raj Gopal V, Falck JR, Spector AA: Oxygenation of omega-3 fatty acids by human cytochrome P450 4F3B: effect on 20-hydroxyeicosatetraenoic acid production. Prostaglandins Leukot Essent Fatty Acids 2006, 75(3): $169-177$

90. Le Quere V, Plee-Gautier E, Potin P, Madec S, Salaun JP: Human CYP4F3s are the main catalysts in the oxidation of fatty acid epoxides. J Lipid Res 2004, 45(8): I446- 1458.

91. Bartoloni L, Antonarakis SE: The human sugar-phosphate/phosphate exchanger family SLC37. Pflugers Arch 2004, 447(5):780-783.

92. Pajor AM: Sodium-coupled transporters for Krebs cycle intermediates. Annu Rev Physiol 1999, 61:663-682.

93. Altmann SW, Davis HR Jr., Zhu LJ, Yao X, Hoos LM, Tetzloff G, lyer SP, Maguire M, Golovko A, Zeng M, Wang L, Murgolo N, Graziano MP: Niemann-Pick CI Like I protein is critical for intestinal cholesterol absorption. Science 2004, 303(566I): I $201-1204$.

94. Wright EM, Turk E: The sodium/glucose cotransport family SLC5. Pflugers Arch 2004, 447(5):5 10-518.

95. Uldry M, Thorens B: The SLC2 family of facilitated hexose and polyol transporters. Pflugers Arch 2004, 26:26.

96. Tazawa S, Yamato T, Fujikura H, Hiratochi M, Itoh F, Tomae M, Takemura $Y$, Maruyama $H$, Sugiyama $T$, Wakamatsu $A$, Isogai $T$, Isaji $M$ : SLC5A9/SGLT4, a new Na+-dependent glucose transporter, is an essential transporter for mannose, $I, 5$-anhydro-D-glucitol, and fructose. Life Sci 2005, 76(9): 1039-1050.

97. Kanai $Y$, Hediger MA: Primary structure and functional characterization of a high-affinity glutamate transporter. Nature 1992, 360(6403):467-47|.

98. Boll M, Daniel H, Gasnier B: The SLC36 family: proton-coupled transporters for the absorption of selected amino acids from extracellular and intracellular proteolysis. Pflugers Arch 2004, 447(5):776-779.

99. Verrey F, Closs El, Wagner CA, Palacin M, Endou H, Kanai Y: CATs and HATs: the SLC7 family of amino acid transporters. Pflugers Arch 2004, 447(5):532-542.

100. Ramadan T, Camargo SM, Summa V, Hunziker P, Chesnov S, Pos KM, Verrey F: Basolateral aromatic amino acid transporter TATI (SIcl6a 10) functions as an efflux pathway. J Cell Physiol 2006, 206(3):77|-779. 
10I. Markovich D, Murer H: The SLCI3 gene family of sodium sulphate/carboxylate cotransporters. Pflugers Arch 2004, 447(5):594-602.

102. Boyer JC, Campbell CE, Sigurdson WJ, Kuo SM: Polarized localization of vitamin C transporters, SVCTI and SVCT2, in epithelial cells. Biochem Biophys Res Commun 2005, 334(I):I50-156.

Publish with Biomed Central and every scientist can read your work free of charge

"BioMed Central will be the most significant development for disseminating the results of biomedical research in our lifetime. " Sir Paul Nurse, Cancer Research UK

Your research papers will be:

- available free of charge to the entire biomedical community

- peer reviewed and published immediately upon acceptance

- cited in PubMed and archived on PubMed Central

- yours - you keep the copyright

Submit your manuscript here:

http://www.biomedcentral.com/info/publishing_adv.asp
BioMedcentral 